\title{
A unique eclogitic source of Guaniamo diamonds, Guyana Shield, Venezuela
}

\author{
Sobolev, N.V. ${ }^{1}$, Yefimova, E.S. ${ }^{1}$, Channer, D. ${ }^{2}$, Anderson, P.F.N. ${ }^{3}$, Barron, K.M. ${ }^{4}$
}

1. Institute of Mineralogy and Petrography, Siberian Branch of the Russian Academy of Sciences, Novosibirsk, 630090, Russia

2. Guaniamo Mining Company, 202-2170 S.E. $17^{\text {th }}$ St. Fort Lauderdale, Florida, USA, 33316

3. 3-668 Euclid Avenue, Toronto, Ontario, Canada, M6G2T7

4. 56 Hartford Trail, Brampton, Ontario, Canada L6W4J8

An alluvial diamond deposit and a number of sills of kimberlitic rocks of Upper Proterozoic age (710 Ma) supplying diamonds to local alluvials are known at Guaniamo, Guyana shield, Venezuela (Channer, Cooper, 1997). The detailed study of diamonds containing mineral inclusions was performed using a representative collection available from current alluvial mining operations, consisting of approximately 3000 crystals, mostly of industrial quality in the $1-2 \mathrm{~mm}$ size fraction. A further 51 diamond with inclusions were selected from available crystals recovered from several kimberlite sills: area 024 ( 34 crystals), La Ceniza (12 crystals) and El Candado (5 crystals). Inclusions are classified into ultramafic or peridotitic (U-type) and eclogitic (E-type) suites following published recommendations (Sobolev, 1977; Meyer, 1987; Gurney, 1989). The available information on Venezuelan diamonds and their inclusions is limited to descriptions of a few rare U-type only including the presence of pyrope, enstatite, spinel and olivine inclusions (Meyer, McCallum, 1993; Nixon et al., 1994). Recently the presence of E-type diamonds within this area was briefly noted (Maltsev et al., 1996). During examination of an available collection a surprising number of pale grass-green pyroxenes and yellow-orange garnets all of eclogitic (E-type) were noted. In total, about 400 diamonds with transparent inclusions were recognized. Often these coexisted with sulfides or other opaque phases.

In half the samples, inclusion bearing diamonds are represented by an equal proportion of octahedral and dodecahedral crystal forms. A further $30 \%$ are transitional between these forms. Fragments, macles and crystal aggregates represent the remaining $20 \%$ of the selection. About half of the crystals are colourless, another half are represented almost equally by diamonds having different hues of green and brown. Green pigmentation spots are a common feature of Guaniamo diamonds. The diamonds are not markedly different in form and colour from the average production of the region (Coenraads et al., 1994). Microdiamonds $(<1 \mathrm{~mm})$ do not show any morphological differences from macrodiamonds.

Mineral inclusions were liberated from 124 alluvial diamonds and 51 diamond crystals from kimberlites and analysed using standard techniques with a CAMEBAX-micro microprobe. All mineral phases are listed in the Table. The absolute majority of studied diamonds $(90 \%)$ contains inclusions of E-type garnets or/and clinopyroxenes. More than half of diamond crystals from studied collection contain more than one (up to four) included mineral phases (see Table).

The major proportion of mineral inclusions analyzed was represented by garnets and omphacitic clinopyroxenes (Table). All studied garnets contain $\mathrm{Fe}, \mathrm{Mg}$ and $\mathrm{Ca}$ in varying proportions and generally correspond very well to the typical range of compositions of E-type garnets from diamonds of worldwide localities. Grossular contents vary from 10.2 to $43.9 \mathrm{~mol} . \%$. Variable proportions of impurities, most notably $\mathrm{TiO}_{2}(0.16-0.84 \mathrm{wt} . \%)$ and $\mathrm{Na}_{2} \mathrm{O}(0.04-0.35 \mathrm{wt} . \%)$, are also typical. The principal variation in clinopyroxene compositions is represented by a broad range of jadeite content, from 20 up to $60 \%$. Significant K content (up to $1.4 \mathrm{wt} . \%$ ) was also found for these omphacites. A number of other minerals were identified during electron probe microanalysis. They include phlogopite, potassic feldspar, corundum, coesite (quartz), magnetite, ilmenite, rutile, and chromite (see Table). Phlogopite with high $\mathrm{TiO}_{2}(10.6 \mathrm{wt} . \%)$ was found as an intergrowth with an omphacite 
grain. Potassic feldspar inclusions, most probably sanidine, were identified from four diamonds (Table). Corundum was documented with garnet and omphacite in a single diamond which represents the first reported occurrence of corundum-bearing polymineralic inclusion assemblage. Coesite was identified in 17 diamonds and confirmed by Raman spectroscopy. Quartz (10 samples) occurs in diamonds with no visible fractures to the surface and most probably represents polymorphic transformation from primary coesite. Magnetite it was observed in two samples with crystal faces in parallelism with faces of the host diamond. These are features of negative crystals and confirm the syngenetic nature of the inclusions. Previously, magnetite inclusions were classified as uncertain (Meyer, 1987). Ilmenite inclusions were detected in three diamonds (see Table). Their compositions are rather similar to that of ilmenites studied from three Brazilian diamonds from an unknown alluvial source (Meyer, 1987). Sulfides were liberated from ten diamonds. They are pyrrhotites showing only traces of $\mathrm{Ni}$, significantly less than $1 \mathrm{wt} . \%$, similar to described sulfides from E-type diamonds (Yefimova et al., 1983).

The local character of inclusion-bearing diamonds from Guaniamo alluvials was confirmed by a comparison with inclusions from kimberlitic diamonds recovered from three sills. 50 diamonds of these sills (i.e. 98\%) contain E-type inclusions with dominating presence of omphacites and subordinate garnets. Such a proportion is similar to inclusion proportion from local alluvial diamonds. High role of silica-rich eclogite assemblages containing coesite and retrograde quartz is also typical of kimberlitic diamonds. Both variations in compositions of garnets and omphacites including such an unusual feature as a stable $\mathrm{K}_{2} \mathrm{O}$ impurity in pyroxenes are similar in two compared suites of inclusions.

We conclude (see Table) that E-type diamonds represent no less than 99.4 per cent of all studied representative collection and this is the highest percentage of such diamonds for the known worlwide localities indicating the uniqueness of the eclogitic source of Guaniamo diamonds. The wide variability in eclogitic environment in which diamonds have been formed under the Guyana shield is well mirrored by the presence of corundum and coesite and also in the extensive range of $\mathrm{Ca}, \mathrm{Fe}$ and $\mathrm{Mg}$ abundance in garnet and $\mathrm{Na}$ contents in clinopyroxenes. This indicates a broadly basaltic chemistry of this environment which probably consists of ancient subducted oceanic crust.This is confirmed by the anomalous negative values of carbon isotope composition for a number of samples.

\section{References}

Channer, D.M.DeR, Cooper, R.E.C., 1997, The Guaniamo diamond region, Bolivar State, Venezuela: a new kimberlite province: Mem. VIII Congreso Geol. Venezolano, Soc. Venez.Geol. vl, p. 143-146.

Coenraads, R.R., Webo, G., Sechos, B., 1994, Alluvial diamond deposits of the Guaniamo region, Bolivar State, Venezuela: The Australian Gemmologist, v. 18(9), p. 287-294.

Gurney, J.J., 1989, Diamonds. In: J. Ross (ed). Kimberlites and Related Rocks: Geol. Soc. Of Australia Spec. Publication, 14, p. 935-965.

Maltsev, K.A., Zakharchenko O.D., San Claudio, A., 1996, Carbon isotope composition of diamonds from Guaniamo placer, Venezuela: $30^{\text {th }}$ Intern. Geol. Congr., Beijing, Abstracts, v. 3, p. 86.

Meyer, H.O.A., 1987, Inclusions in diamonds. In: P.H.Nixon (ed). Mantle Xenoliths: John Wiley and Sons, Chichester, England.,p. 501-522.

Meyer, H.O.A., McCallum, M.E., 1993, Diamonds and their sources in the Venezuela portion of the Gyana Shield: Econ. Geol., 88, p. 989-998. 
Nixon, P.H., Griffin, W.L., Davies, G.R., Condliffe, E., 1994, Cr-garnet indicators in Venezuela kimberlites and their bearing on the evolution of the Guyana Craton. In: Proc. Of the $5^{\text {th }}$ Intern.Kimberlite Conf., Araxa, Brazil: CPRM Spec. Publ. 1A, Brasilia, p. 378-387.

Sobolev, N.V., 1974, Deep-seated inclusions in kimberlites and the problem of the composition of the Upper Mantle (in Russian): Novosibirsk, Nauka, 263 p. English Translation by D.A.Brown, F.R.Boyd (ed), 1977, AGU, Washington D.C., 279 p.

Yefimova, E.S., Sobolev, N.V., Pospelova, L.N., 1983, Sulfide inclusions in diamonds and specific features of their paragenesis (in Russian): Zap. Vses. Miner. Obshch., v. 112, p. 300-310.

Table . Parageneses of inclusions from studied diamonds

\begin{tabular}{|l|rl|}
\hline \multicolumn{1}{|c|}{ Included minerals } & $\begin{array}{r}\text { Number of diamonds including those containing } \\
\text { additionally sulfide inclusions (in brackets) }\end{array}$ \\
\hline Ga & 16 & $(4)$ \\
Cpx & 36 & $(7)$ \\
Cs/Q & 4 & $(3)$ \\
Snd & 2 & \\
Ga, Cpx & 25 & $(13)$ \\
Ga, Cs & 6 & $(2)$ \\
Ga, Ru & 1 & \\
Ga, Mt & 3 & $(2)$ \\
Cpx, Cs/Q & 8 & $(2)$ \\
Cpx, Ru & 2 & $(1)$ \\
Cpx, Mt & 2 & $(1)$ \\
Cpx, Phl & 1 & \\
Ilm, Mt & 2 & $(1)$ \\
Ru, Mt & 1 & \\
Ga, Cpx, Cs & 3 & $(1)$ \\
Ga, Cpx, Cor & 1 & \\
Ga, Cpx, Ru & 2 & $(1)$ \\
Ga, Cpx, Snd & 1 & $(1)$ \\
Ga, Q, Snd & 1 & $(1)$ \\
Cpx, Cs, Ru & 1 & $(1)$ \\
Cpx, Q, Mt & 1 & $(1)$ \\
Ru, Ilm, Q & 1 & $(1)$ \\
Ga, Cpx, Q, Mt & 1 & $(1)$ \\
Ga, Ru, Q, Mt & 1 & $(1)$ \\
\hline E-type & 122 & $(45)$ \\
\hline Chr & 2 & \\
\hline U-type & 2 & \\
\hline Total & 124 & \\
\hline Visual examination: & & \\
E-type & 205 & \\
U-type & 0 & \\
\hline Total & 329 & \\
\hline E/E+U (\%) & 99,4 & \\
\hline & & \\
\hline
\end{tabular}

Note: Ga, garnet; $\mathrm{Cpx}$, clinopyroxene; $\mathrm{Cs}$, coesite; $\mathrm{Q}$, quartz; Snd, sanidine; Ru, rutile; Mt, magnetite; Phl, phlogopite; Cor, corundum; Ilm, ilmenite; $\mathrm{Chr}$, chromite; Ol, olivine. 